\title{
Model Epidemik SIRS pada Pecandu Game Online
}

\author{
Cindy Aisa Putri Noor1, Salma Septia Ibrahim², Siti Maryam Barham³ \\ 1,2,3 Jurusan Matematika, Fakultas MIPA, Universitas Negeri Gorontalo, \\ Jl. Prof. Dr. Ing. B. J. Habibie, Tilongkabila, Kabupaten Bone Bolango, Gorontalo 96119, Indonesia
}

Email Korespondensi: septiaibrahim@gmail.com

\begin{abstract}
ABSTRAK
Game online merupakan permainan komputer yang melibatkan jaringan internet untuk menghubungkan para pemain dari berbagai belahan dunia. Jumlah gamer di Indonesa saat ini diprediksi mencapai 34 juta orang. Kebanyakan dari mereka adalah remaja. Dimana game online sendiri mempunyai beberapa daya tarik yang membuat remaja lebih memilih bermain daripada belajar. Untuk melihat dinamika pecandu game online di Indonesia, kami melakukan penelitian dengan memodelkannya dalam bentuk model epidemik SIRS. Dari model tersebut diperoleh dua jenis titik tetap yaitu titik tetap bebas pecandu game online $\left(E_{1}\right)$ dan titik tetap endemik $\left(E_{2}\right)$. Kemudian menganalisi kestabilan dari kedua titik tetap tersebut. Setelah itu, menentukan nilai reproduksi dasar $\left(R_{0}\right)$ dan melakukan simulasi model untuk menentukan dinamika populasi pecandu game online. Pada saat kondisi $R_{0}<1$ maka populasi pecandu game online akan menghilang dan pada kondisi $R_{0}>1$ maka populasi pecandu game online akan meningkat. Setelah itu, hasil yang diperoleh diinterpretasikan sebagai solusi dari masalah tersebut, yaitu untuk mengurangi populasi pecandu game online maka kita harus mengurangi laju perubahan yang rentan bermain game ke individu yang aktif bermain dan menambah parameter laju perubahan individu yang aktif bermain ke berhenti bermain.
\end{abstract}

\section{Kata Kunci:}

Model Epidemik; SIRS; Game Online

\section{Pendahuluan}

Kecanduan adalah kondisi yang terjadi ketika seseorang memasukkan suatu zat kedalam tubuhnya (misalnya alkohol, kokain, nikotin) atau melakukan suatu kegiatan (misalnya bermain game, belanja, judi) dan merasakan kesenangan darinya tetapi dia tidak sanggup membatasinya[1]. Di zaman yang modern ini, banyak orang yang menggunakan teknologi dalam melakukan aktifitas sehari-hari. Salah satunya penggunaan teknologi dalam bermain game. Saat ini bermain game maerupakan suatu kegemaran diberbagai kalangan. Sehingga banyak orang yang menjadi pecandu game, terutama game online.

Game online merupakan permainan (games) yang dapat diakses oleh banyak pemain, di mana mesin-mesin yang digunakan pemain dihubungkan oleh suatu jaringan, umumnya jaringan yang digunakan adalah Internet[2]. Melalui game online, manusia bisa berinteraksi antar sesama dan bisa menjadi opsi dalam menghilangkan penat. Game online juga dapat dijadikan sebagai media untuk belajar dan melatih kemampuan manusia dalam berpikir serta berkomunikasi, melalui game online juga kita dapat mengetahui perkembangan teknologi sehingga mampu menambah ilmu pengetahuan. Akan tetapi game online bisa membuat kesehatan para pemain akan menurun. Game juga dapat mempengaruhi prestasi belajar. Bisa juga para pemain game terkena 
gangguan mental karena banyaknya adegan di game yang dapat mengajarkan untuk melakukan tindakan kekerasan seperti perkelahian.

Depresi adalah suatu penyakit jiwa dengan gejala utama sedih, yang disertai gejalagejala psikologik lainnya, gangguan somatik maupun gangguan psikomotor dalam kurun waktu tertentu dan digolongkan ke dalam gangguan afektif[3]. Depresi juga bisa disebabkan karena kecanduan game online. Pecandu game online biasanya akan merasa ketagihan untuk menyelesaikan suatu misi atau permainan dengan nilai (score) yang tinggi secara terus menerus. Sehingga interaksi sosial pecandu game online dengan lingkungannya semakin rendah dan bisa membuat mereka depresi jika mereka tidak bisa menyelesaikan suatu misi dari game online tersebut.

Kematian adalah dampak yang sangat fatal saat seseorang telah kecanduan game online, karena saat bermain game orang akan merasa asyik dan lupa dengan waktu, tanpa ia sadari ia telah menghabiskan beberapa jam didepan komputer dengan melototi layar, yang pancaran cahayanya dapat merusak mata[4].

Game online dapat diakses melalui jaringan internet. Oleh karena itu, seiring meningkatnya pengguna internet, maka pengguna game online di Indonesia juga meningkat. Berdasarkan data Asosiasi Penyelenggara Jasa Internet di Indonesia (APJII), pertumbuhan pengguna internet dari tahun 2013 sampai pada tahun 2017 meningkat dari 82 juta jiwa menjadi 143,26 juta jiwa. 70\% pemain game online di Indonesia berusia 13-17 tahun dan 18-24 tahun[5][6].

Dalam matematika, pecandu game online dapat dimodelkan dengan model epidemik SIRS. Pada model ini, populasi yang diamati menjadi tiga kompartemen, yaitu individu yang tidak atau rentan bermain game online $S$ (susceptible), individu yang aktif bermain atau pecandu game online I (infectives), dan individu yang berhenti bermain namun masih berpeluang untuk bermain kembali $R$ (recovery). Tujuan penelitian ini yaitu untuk melihat dinamika populasi pada pecandu game online.

\section{Metode}

Penelitian ini menggunakan metode penelitian kepustakaan (liberary research ). Pada penelitian ini dilakukan kajian terhadap buku, jurnal, dan artikel-artikel ilmiah mengenai pecandu game online dan mengkaji model tipe SIRS.

Pada penelitian ini, adapun langkah-langkah yang dilakukan adalah

1. Memodelkan masalah kedalam model SIRS,

2. Menentukan titik tetap,

3. Menentukan matriks Jacobi,

4. Menganalisis kestabilan titik tetap, dan

5. Simulasi

\section{Hasil dan Pembahasan}

\subsection{Model Matematika}

Model yang akan kami bahas dalam penelitian ini adalah model epidemi tipe SIRS yang terdiri dari 3 kelompok yaitu Suspectibel (S), Infected (I), dan Recovered (R). Asumsiasumsi yang digunakan dalam pada penelitian ini yaitu :

1. Jumlah kelahiran dan kematian $(\mu)$ dianggap konstan.

2. Individu yang aktif bermain diasumsikan meninggal secara alami dan ada yang meninggal karena kecanduan bermain game. 
3. Jika individu yang tidak bermain game (S) berinteraksi dengan individu yang bermain game maka individu tersebut akan menjadi pemain aktif (I).

4. Individu yang sudah berhenti bermain $(R)$ berpeluang untuk menjadi individu yang rentan (S), dapat diasumsikan pula seseorang yang telah berhenti bermain tidak akan kembali bermain game karena adanya kesadaran seseorang pada dampak negatif dari game.

5. Perubahan individu rentan dan jarang bermain proposional terhadap jumlah populasi.

Berdasarkan asumsi asumsi diatas maka didapatkan skema model tipe SIRS pada populasi pemain game dalam bentuk diagram kompartmen pada Gambar 1.

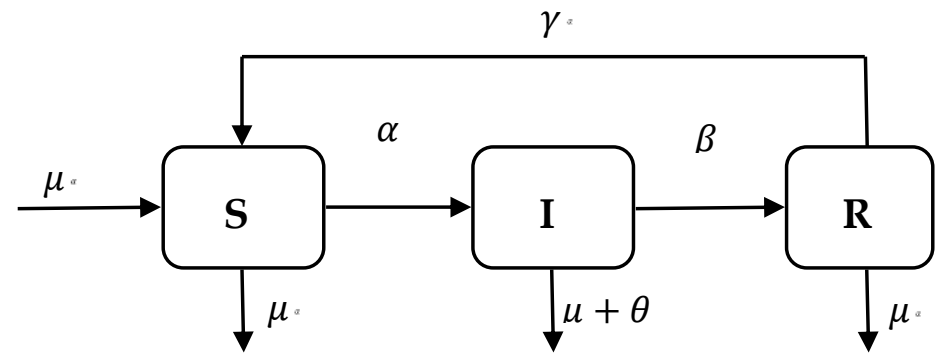

Gambar 1. Model epidemik SIRS pada pecandu game online

Berdasarkan skema model tipe SIRS diatas maka model matematika

$$
\left\{\begin{array}{l}
\frac{d S}{d t}=\mu N-\alpha S \frac{I}{N} \gamma R-\mu S \\
\frac{d I}{d t}=\alpha S \frac{I}{N}-\beta I-(\mu+\theta) I \\
\frac{d R}{d t}=\beta I-\gamma R-\mu R
\end{array}\right.
$$

Pada penelitian ini kami menggunakan beberapa variabel dan parameter yang disajikan pada Tabel 1.

Tabel 1. Variabel dan parameter model epidemik SIRS pada pecandu game online

\begin{tabular}{|c|c|}
\hline Notasi & Keterangan \\
\hline$S$ & Populasi yang rentan atau tidak bermain game online \\
\hline$I$ & Populasi yang aktif bermain game online \\
\hline$R$ & $\begin{array}{l}\text { Populasi yang telah berhenti bermain game online namun masih } \\
\text { berpeluang untuk bermain kembali }\end{array}$ \\
\hline$\mu$ & Laju kelahiran dan kematian setiap satuan waktu \\
\hline$\alpha$ & $\begin{array}{l}\text { Laju perubahan populasi yang tidak main game atau rentan bermain } \\
\text { game ke individu aktif bermain }\end{array}$ \\
\hline$\beta$ & $\begin{array}{l}\text { Laju perubahan populasi yang aktif bermain ke berhenti bermain karena } \\
\text { faktor umur, kesehatan, bosan, atau bisa juga tidak lagi memiliki waktu } \\
\text { luang untuk bermain game }\end{array}$ \\
\hline$\gamma$ & $\begin{array}{l}\text { Laju perubahan populasi yang berhenti bermain game ke individu yang } \\
\text { rentan bermain game }\end{array}$ \\
\hline$\theta$ & Laju kematian akibat kecanduan bermain game \\
\hline
\end{tabular}

\subsection{Analisis Model}

\subsubsection{Titik Tetap Model}


Kestabilan dari populasi pemain game online dapat ditentukan dengan mencari suatu titik tetap pada populasi pemain game online tipe SIRS, yang dapat diperoleh dari sistem persamaan $s(t)=0, i(t)=0, r(t)=0$. Maka, didapatkan dua titik tetap yaitu:

1. Titik tetap bebas pecandu game online

$$
\left(E_{1}\right)=(1,0,0)
$$

2. Titik tetap endemik

$$
\left(E_{2}\right)=\left(\frac{\beta+\mu+\theta}{\alpha}, \frac{\mu(\gamma+\mu)(\alpha-\beta-\mu-\theta)}{\alpha\left(\gamma \mu+\gamma \theta+\mu \beta+\mu^{2}+\mu \theta\right)}, \frac{\mu \beta(\alpha-\beta-\mu-\theta)}{\alpha\left(\gamma \mu+\gamma \theta+\mu \beta+\mu^{2}+\mu \theta\right)}\right)
$$

\subsubsection{Analisis Kestabilan TitikTetap}

Model epidemik SIRS terhadap pecandu game oline merupakan sistem persamaan diferensial non linear. Untuk menganalisis kestabilan titik tetap suatu sistem persamaan diferensial nonlinear, dapat dilakukan dengan melinearkan persamaan diferensialnya. Analisis kestabilan titip tetap dapat ditentukan dengan cara menentukan nilai eigen dari matriks Jacobian sistem. Matriks Jacobian dari sistem adalah:

$$
J=\left[\begin{array}{ccc}
-(\alpha i+\mu) & -\alpha s & \gamma \\
\alpha i & \alpha s-\beta-(\mu+\theta) & 0 \\
0 & \beta & -(\gamma+\mu)
\end{array}\right]
$$

Untuk memperoleh kestabilan sistem di titik $E_{1}$ terlebih dahulu dilakukan pelinearan di sekitar titik tetap $E_{1}$, yaitu dengan mensubtitusi nilai dari (3) ke (5). Sehingga diperoleh matriks Jacobian dari titik tetap pertama $\left(J E_{1}\right)$ :

$$
J E_{1}=\left[\begin{array}{ccc}
-\mu & -\alpha & \gamma \\
0 & \alpha-(\beta+\mu+\theta) & 0 \\
0 & \beta & -(\gamma+\mu)
\end{array}\right]
$$

Dengan menyelesaikan persamaan karakteristik $\operatorname{det}\left(\lambda I-J E_{1}\right)=0$. Maka akan di dapatkan nilai-nilai eigen dari (6), yaitu:

$$
\left\{\begin{array}{l}
\lambda_{1}=-\mu \\
\lambda_{2}=\alpha-(\beta+\mu+\theta) \\
\lambda_{3}=-(\gamma+\mu)
\end{array}\right.
$$

Karena, $\lambda_{1}<0, \lambda_{3}<0$ dan titik tetap $E_{1}$ akan stabil jika $\lambda_{2}$ bernilai negatif, sehingga:

$$
\begin{gathered}
\alpha-(\beta+\mu+\theta)<0 \\
\alpha<(\beta+\mu+\theta)
\end{gathered}
$$

Untuk memperoleh kestabilan sistem di titik $E_{2}$ terlebih dahulu dilakukan pelinearan di sekitar titik tetap $E_{2}$, yaitu dengan mensubtitusi nilai dari (4) ke (5). Sehingga diperoleh matriks Jacobian dari titik tetap pertama $\left(J E_{2}\right)$ :

$$
J E_{2}=\left[\begin{array}{ccc}
\frac{\mu(\gamma+\mu)(\alpha-\beta-\mu-\theta)}{\gamma \mu+\gamma \theta+\mu \beta+\mu^{2}+\mu \theta}+\mu & -(\beta+\mu+\theta) & \gamma \\
\frac{\mu(\gamma+\mu)(\alpha-\beta-\mu-\theta)}{\gamma \mu+\gamma \theta+\mu \beta+\mu^{2}+\mu \theta} & 0 & 0 \\
0 & \beta & -(\gamma+\mu)
\end{array}\right]
$$

Dengan menyelesaikan persamaan karakteristik $\operatorname{det}\left(\lambda I-J E_{1}\right)=0$. Maka diperoleh: 


$$
\begin{aligned}
& \left|\begin{array}{ccc}
\lambda-\left(\frac{\mu(\gamma+\mu)(\alpha-\beta-\mu-\theta)}{\gamma \mu+\gamma \theta+\mu \beta+\mu^{2}+\mu \theta}+\mu\right) & -(\beta+\mu+\theta) & \gamma \\
\frac{\mu(\gamma+\mu)(\alpha-\beta-\mu-\theta)}{\gamma \mu+\gamma \theta+\mu \beta+\mu^{2}+\mu \theta} & \lambda & 0 \\
0 & \beta & \lambda+(\gamma+\mu)
\end{array}\right|=0 \\
& \left(\lambda-\left(\frac{\mu(\gamma+\mu)(\alpha-\beta-\mu-\theta)}{\gamma \mu+\gamma \theta+\mu \beta+\mu^{2}+\mu \theta}+\mu\right)\right)(\lambda)(\lambda+(\gamma+\mu))+(\gamma)\left(\frac{\mu(\gamma+\mu)(\alpha-\beta-\mu-\theta)}{\gamma \mu+\gamma \theta+\mu \beta+\mu^{2}+\mu \theta}\right)(\beta)+(\beta+\mu+ \\
& \theta)\left(\frac{\mu(\gamma+\mu)(\alpha-\beta-\mu-\theta)}{\gamma \mu+\gamma \theta+\mu \beta+\mu^{2}+\mu \theta}\right)(\lambda+(\gamma+\mu))=0
\end{aligned}
$$

Dengan memisalkan,

$$
\begin{aligned}
& \omega_{4}=\frac{\mu(\gamma+\mu)(\alpha-\beta-\mu-\theta)}{\gamma \mu+\gamma \theta+\mu \beta+\mu^{2}+\mu \theta} \\
& \omega_{5}=\gamma+\mu \\
& \omega_{6}=\beta+\mu+\theta
\end{aligned}
$$

Maka diperoleh hasil sebagai berikut:

$\lambda^{3}+\left(\omega_{5}-\omega_{4}+\mu\right) \lambda^{2}+\left(-\omega_{4} \omega_{5}+\mu \omega_{5}-\omega_{6} \omega_{4}\right) \lambda+\left(\gamma \beta-\omega_{6} \omega_{5}\right) \omega_{4}=0$

Dimana koefisien setiap $\lambda$-nya yaitu,

$$
\left\{\begin{array}{c}
\quad c_{0}=1 \\
c_{1}=\gamma+2 \mu-\left(\frac{\mu(\gamma+\mu)(\alpha-\beta-\mu-\theta)}{\gamma \mu+\gamma \theta+\mu \beta+\mu^{2}+\mu \theta}\right) \\
c_{2}=\mu(\gamma+\mu)-(\gamma+2 \mu+\beta+\theta)\left(\frac{\mu(\gamma+\mu)(\alpha-\beta-\mu-\theta)}{\gamma \mu+\gamma \theta+\mu \beta+\mu^{2}+\mu \theta}\right) \\
c_{3}=(\gamma \beta-(\beta+\mu+\theta)(\gamma+\mu))\left(\frac{\mu(\gamma+\mu)(\alpha-\beta-\mu-\theta)}{\gamma \mu+\gamma \theta+\mu \beta+\mu^{2}+\mu \theta}\right)
\end{array}\right.
$$

Karena nilai eigen pada (10) sulit dicari maka digunakan kriteria Routh Hurwitz untuk menganalisis titik tetapnya. Menurut kriteria Routh Hurwitz, titik tetap $E_{2}$ akan stabil jika dan hanya jika semua nilai eigen adalah real negatif. Hal ini terjadi jika memenuhi syarat sebagai berikut:

$$
\begin{gathered}
c_{1}>0, c_{3}>0,{\text { dan } c_{1} c_{2}-c_{3}>0}_{c_{1}>0} \\
\gamma+2 \mu-\left(\frac{\mu(\gamma+\mu)(\alpha-\beta-\mu-\theta)}{\gamma \mu+\gamma \theta+\mu \beta+\mu^{2}+\mu \theta}\right)>0 \\
\frac{(\gamma+2 \mu)\left(\gamma \mu+\gamma \theta+\mu \beta+\mu^{2}+\mu \theta\right)-(\mu(\gamma+\mu)(\alpha-\beta-\mu-\theta))}{\gamma \mu+\gamma \theta+\mu \beta+\mu^{2}+\mu \theta}>0 \\
(\gamma+2 \mu)\left(\gamma \mu+\gamma \theta+\mu \beta+\mu^{2}+\mu \theta\right)-\mu(\gamma+\mu) \alpha+\mu(\gamma+\mu) \beta+\mu(\gamma+\mu) \mu+\mu(\gamma+\mu) \theta \\
>0 \\
(\gamma+2 \mu)\left(\gamma \mu+\gamma \theta+\mu \beta+\mu^{2}+\mu \theta\right)+\mu(\gamma+\mu) \beta+\mu(\gamma+\mu) \mu+\mu(\gamma+\mu) \theta>\mu(\gamma+\mu) \alpha \\
\frac{(\gamma+2 \mu)\left(\gamma \mu+\gamma \theta+\mu \beta+\mu^{2}+\mu \theta\right)+\mu(\gamma+\mu) \beta+\mu(\gamma+\mu) \mu+\mu(\gamma+\mu) \theta}{\mu(\gamma+\mu) \alpha}>1
\end{gathered}
$$




$$
\begin{gathered}
c_{3}>0 \\
(\gamma \beta-(\beta+\mu+\theta)(\gamma+\mu))\left(\frac{\mu(\gamma+\mu)(\alpha-\beta-\mu-\theta)}{\gamma \mu+\gamma \theta+\mu \beta+\mu^{2}+\mu \theta}\right)>0 \\
(\gamma \beta-(\beta+\mu+\theta)(\gamma+\mu))(\mu(\gamma+\mu)(\alpha-\beta-\mu-\theta))>0 \\
\gamma \beta(\mu(\gamma+\mu)(\alpha-\beta-\mu-\theta))-(\beta+\mu+\theta)(\gamma+\mu)(\mu(\gamma+\mu)(\alpha-\beta-\mu-\theta))>0 \\
\gamma \beta(\mu(\gamma+\mu)(\alpha-(\beta+\mu+\theta)))-(\beta+\mu+\theta)(\gamma+\mu)(\mu(\gamma+\mu)(\alpha-(\beta+\mu+\theta)))>0 \\
\gamma \beta \mu(\gamma+\mu) \alpha-\gamma \beta \mu(\gamma+\mu)(\beta+\mu+\theta)-\mu \alpha(\beta+\mu+\theta)(\gamma+\mu)^{2} \\
+\mu(\beta+\mu+\theta)(\gamma+\mu)^{2}(\beta+\mu+\theta)>0 \\
\gamma \beta \mu(\gamma+\mu) \alpha+\mu(\beta+\mu+\theta)(\gamma+\mu)^{2}(\beta+\mu+\theta) \\
>\gamma \beta \mu(\gamma+\mu)(\beta+\mu+\theta)+\mu \alpha(\beta+\mu+\theta)(\gamma+\mu)^{2} \\
\frac{\gamma \beta \mu(\gamma+\mu) \alpha+\mu(\beta+\mu+\theta)(\gamma+\mu)^{2}(\beta+\mu+\theta)}{\gamma \beta \mu(\gamma+\mu)(\beta+\mu+\theta)+\mu \alpha(\beta+\mu+\theta)(\gamma+\mu)^{2}}>1
\end{gathered}
$$

Untuk yang $c_{1} c_{2}-c_{3}>0$ misalkan:

$$
\begin{aligned}
& \omega_{5}=\gamma+\mu \\
& \omega_{6}=\beta+\mu+\theta \\
& \omega_{7}=\gamma \mu+\gamma \theta+\mu \beta+\mu^{2}+\mu \theta
\end{aligned}
$$

$$
\begin{gathered}
c_{1} c_{2}-c_{3}>0 \\
\left((\gamma+2 \mu)-\left(\frac{\mu(\gamma+\mu)(\alpha-\beta-\mu-\theta)}{\gamma \mu+\gamma \theta+\mu \beta+\mu^{2}+\mu \theta}\right)\right)(\mu(\gamma+\mu) \\
\left.-(\gamma+2 \mu+\beta+\theta)\left(\frac{\mu(\gamma+\mu)(\alpha-\beta-\mu-\theta)}{\gamma \mu+\gamma \theta+\mu \beta+\mu^{2}+\mu \theta}\right)\right) \\
-\left((\gamma \beta-(\beta+\mu+\theta)(\gamma+\mu))\left(\frac{\mu(\gamma+\mu)(\alpha-\beta-\mu-\theta)}{\gamma \mu+\gamma \theta+\mu \beta+\mu^{2}+\mu \theta}\right)\right)>0 \\
\left(\left(\omega_{5}+\mu\right)-\left(\frac{\mu \omega_{5}\left(\alpha-\omega_{6}\right)}{\omega_{7}}\right)\right)\left(\mu \omega_{5}-\left(\omega_{5}+\omega_{6}\right)\left(\frac{\mu \omega_{5}\left(\alpha-\omega_{6}\right)}{\omega_{7}}\right)\right) \\
-\left(\left(\gamma \beta-\omega_{6} \omega_{5}\right)\left(\frac{\mu \omega_{5}\left(\alpha-\omega_{6}\right)}{\omega_{7}}\right)\right)>0
\end{gathered}
$$

$\left(\omega_{5}+\mu\right) \mu \omega_{5} \omega_{7}^{2}+\omega_{7}\left(\mu \omega_{5} \omega_{6}\left(\omega_{5}+\mu\right)\left(\omega_{5}+\omega_{6}\right)+\alpha \mu \omega_{5} \gamma \beta+\mu \omega_{5} \omega_{6} \gamma \beta+\alpha \mu \omega_{5}{ }^{2} \omega_{6}\right)$

$+\left(\omega_{5}+\omega_{6}\right)\left(\left(\alpha \mu \omega_{5}\right)^{2}+\left(\mu \omega_{5} \omega_{6}\right)^{2}\right)$

$-\left(\left(\alpha \mu \omega_{5}\left(\omega_{5}+\mu\right)\left(\omega_{5}+\omega_{6}\right)+\alpha\left(\mu \omega_{5}\right)^{2}+\left(\mu \omega_{5}\right)^{2} \omega_{6}+\alpha \mu \omega_{5} \gamma \beta\right.\right.$

$\left.\left.+\mu \omega_{5} \omega_{6}^{2} \omega_{5}\right) \omega_{7}+\alpha \mu^{2} \omega_{5}^{2} \omega_{6}\left(\omega_{5}+\omega_{6}\right)\right)>0$

$\left(\omega_{5}+\mu\right) \mu \omega_{5} \omega_{7}^{2}+\omega_{7}\left(\mu \omega_{5} \omega_{6}\left(\omega_{5}+\mu\right)\left(\omega_{5}+\omega_{6}\right)+\alpha \mu \omega_{5} \gamma \beta+\mu \omega_{5} \omega_{6} \gamma \beta+\alpha \mu \omega_{5}^{2} \omega_{6}\right)$

$+\left(\omega_{5}+\omega_{6}\right)\left(\left(\alpha \mu \omega_{5}\right)^{2}+\left(\mu \omega_{5} \omega_{6}\right)^{2}\right)$

$>\left(\alpha \mu \omega_{5}\left(\omega_{5}+\mu\right)\left(\omega_{5}+\omega_{6}\right)+\alpha\left(\mu \omega_{5}\right)^{2}+\left(\mu \omega_{5}\right)^{2} \omega_{6}+\alpha \mu \omega_{5} \gamma \beta\right.$

$\left.+\mu \omega_{5} \omega_{6}^{2} \omega_{5}\right) \omega_{7}+\alpha \mu^{2} \omega_{5}^{2} \omega_{6}\left(\omega_{5}+\omega_{6}\right)$

$\left(\omega_{5}+\mu\right) \mu \omega_{5} \omega_{7}^{2}+\omega_{7}\left(\mu \omega_{5} \omega_{6}\left(\omega_{5}+\mu\right)\left(\omega_{5}+\omega_{6}\right)+\alpha \mu \omega_{5} \gamma \beta+\mu \omega_{5} \omega_{6} \gamma \beta+\alpha \mu \omega_{5}{ }^{2} \omega_{6}\right)+\left(\omega_{5}+\omega_{6}\right)\left(\left(\alpha \mu \omega_{5}\right)^{2}\right.$

$\left(\alpha \mu \omega_{5}\left(\omega_{5}+\mu\right)\left(\omega_{5}+\omega_{6}\right)+\alpha\left(\mu \omega_{5}\right)^{2}+\left(\mu \omega_{5}\right)^{2} \omega_{6}+\alpha \mu \omega_{5} \gamma \beta+\mu \omega_{5} \omega_{6}^{2} \omega_{5}\right) \omega_{7}+\alpha \mu^{2} \omega_{5}^{2} \omega_{6}\left(\omega_{5}+\right.$ $>1$

Karena nilai $c_{1}>0, c_{3}>0$, dan $c_{1} c_{2}-c_{3}>0$ terpenuhi, maka titik tetap $E_{2}$ dikatakan stabil.

\subsubsection{Bilangan Repoduksi Dasar}


Untuk menentukan bilangan reproduksi dasar, dapat digunakan matriks next generation. Bilangan reproduksi dasar didefinisikan sebagai radius spektral (nilai eigen dominan) dari matriks next generation [7][8][9]. Maka dari model yang telah dibentuk diperoleh bilangan reproduksi dasar sebagai berikut:

$$
R_{0}=\frac{\alpha}{\beta+\mu+\theta}
$$

Jika $R_{0}<1$ maka pecandu game online akan menghilang.

Jika $R_{0}>1$ maka pecandu game online meningkat menjadi wabah.

\subsection{Simulasi dan Interpretasi Model}

Pada bagian simulasi ini, diamati dinamika populasi dalam dua kondisi, yaitu ketika $R_{0}<1$ dan $R_{0}>1$

Untuk melakukan simulasi maka diperlukan populasi awal danbeberapa parameter yang mendukung. Nilai populasi awal $s(0)=20, i(0)=12, r(0)=3$ dan nilai-nilai parameter dapat diperoleh dari data sekunder dan bisa juga berdasarkan asumsi. Nilainilai parameter yang digunakan pada simulasi ini disajikan pada Tabel 2 dan Tabel 3.

Table 2. Nilai-nilai parameter untuk kondisi $R_{0}<1$

\begin{tabular}{lccc}
\hline \multicolumn{1}{c}{ Parameter } & Notasi & $R_{0}<1$ & Keterangan \\
\hline $\begin{array}{l}\text { Laju kelahiran dan kematian setiap } \\
\text { satuan waktu }\end{array}$ & $\mu$ & 1 & Asumsi \\
$\begin{array}{l}\text { Laju perubahan populasi yang tidak } \\
\text { main game atau rentan bermain } \\
\text { game ke individu aktif bermain }\end{array}$ & $\alpha$ & 0.9286 & Asumsi \\
$\begin{array}{l}\text { Laju perubahan populasi yang aktif } \\
\text { bermain ke berhenti bermain karena } \\
\text { faktor umur, kesehatan, bosan, atau } \\
\text { bisa juga tidak lagi memiliki waktu }\end{array}$ & $\beta$ & 0.2307 & Asumsi \\
$\begin{array}{l}\text { luang untuk bermain game. } \\
\begin{array}{l}\text { Laju perubahan populasi yang } \\
\text { berhenti bermain game ke individu } \\
\text { yang rentan bermain game. }\end{array}\end{array}$ & $\gamma$ & 4.67 & Asumsi \\
$\begin{array}{l}\text { Laju kematian akibat kecanduan } \\
\text { bermain game }\end{array}$ & $\theta$ & 0 & Asumsi \\
\hline
\end{tabular}

Tabel 3. Nilai-nilai parameter untuk kondisi $R_{0}>1$

\begin{tabular}{lccc}
\hline \multicolumn{1}{c}{ Parameter } & Notasi & $R_{0}>1$ & Referensi \\
\hline $\begin{array}{l}\text { Laju kelahiran dan kematian setiap } \\
\text { satuan waktu }\end{array}$ & $\mu$ & 0.0149 & {$[10]$}
\end{tabular}


Laju perubahan populasi yang tidak main game atau rentan bermain game ke individu aktif bermain

Laju perubahan populasi yang aktif bermain ke berhenti bermain karena faktor umur, kesehatan, bosan, atau $\begin{array}{lll}\beta & 0.07 \quad \text { Asumsi }\end{array}$ bisa juga tidak lagi memiliki waktu luang untuk bermain game.

Laju perubahan populasi yang berhenti bermain game ke individu yang rentan bermain game. Laju kematian akibat kecanduan bermain game

$\begin{array}{lll}\gamma & 0.02 & \text { Asumsi } \\ \theta & 0.01 & \text { Asumsi }\end{array}$

Untuk melihat dinamika populasi pada kondisi $R_{0}<1$ dan $R_{0}>1$ dapat menggunakan software Maple.
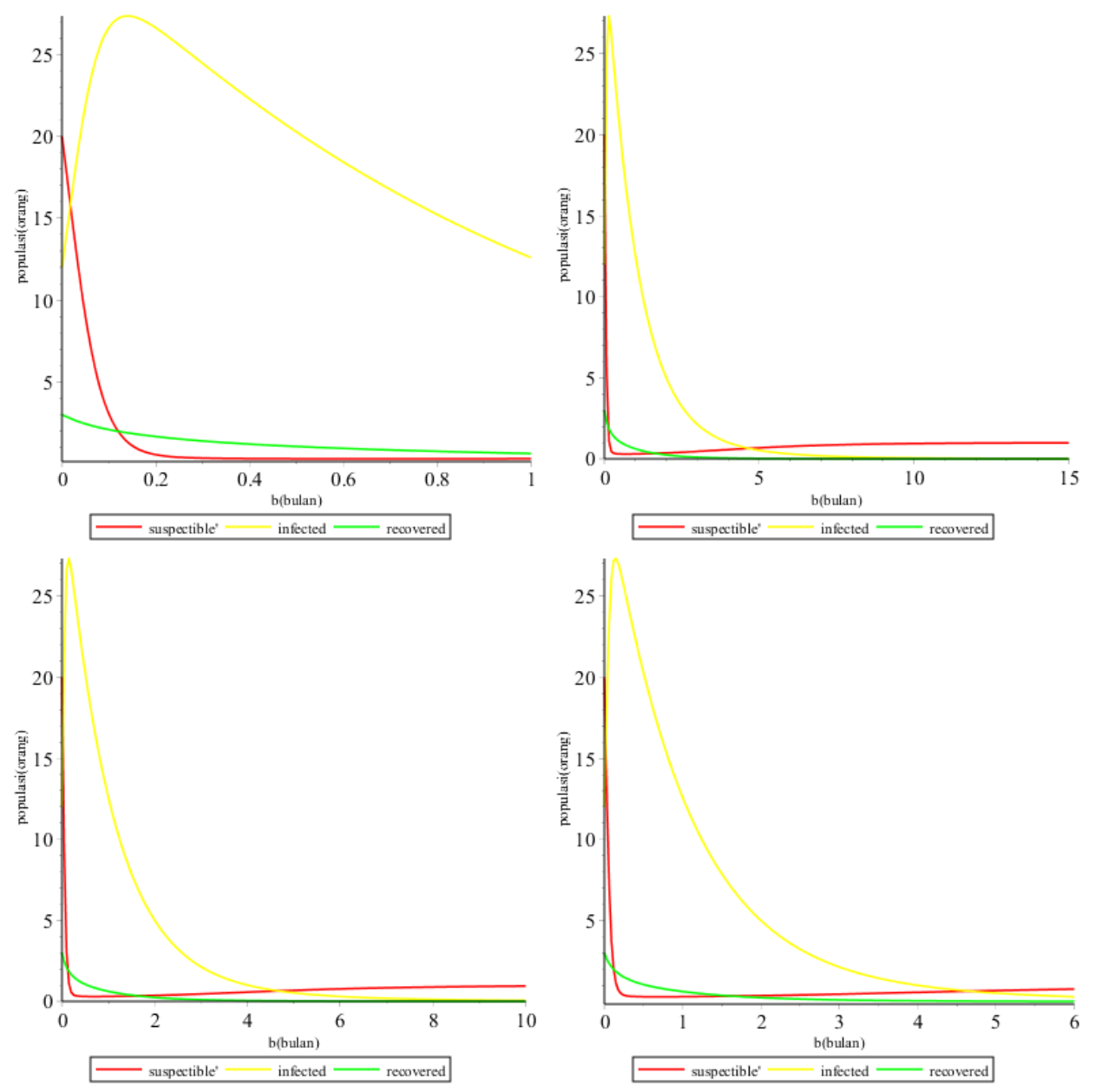

Gambar 2. Dinamika populasi pada kondisi $R_{0}<1$

Pada Gambar 1 dapat dilihat bahwa semua populasi akan menuju titik tetap bebas pecandu game online $\left(E_{1}\right)=(s=1, i=0, r=0)$. Populasi suspectible (merah) akan menurun kemudian naik pada saat bulan ke-1 dan akan stabil pada bulan ke-10. Populasi infected (kuning) akan meningkat kemudian pada saat bulan ke 0.2 populasi 
infected (kuning) akan menurun dan akan stabil pada saat bulan ke-8. Populasi recovered (hijau) akan menurun dan menjadi stabil pada bulan ke-5.
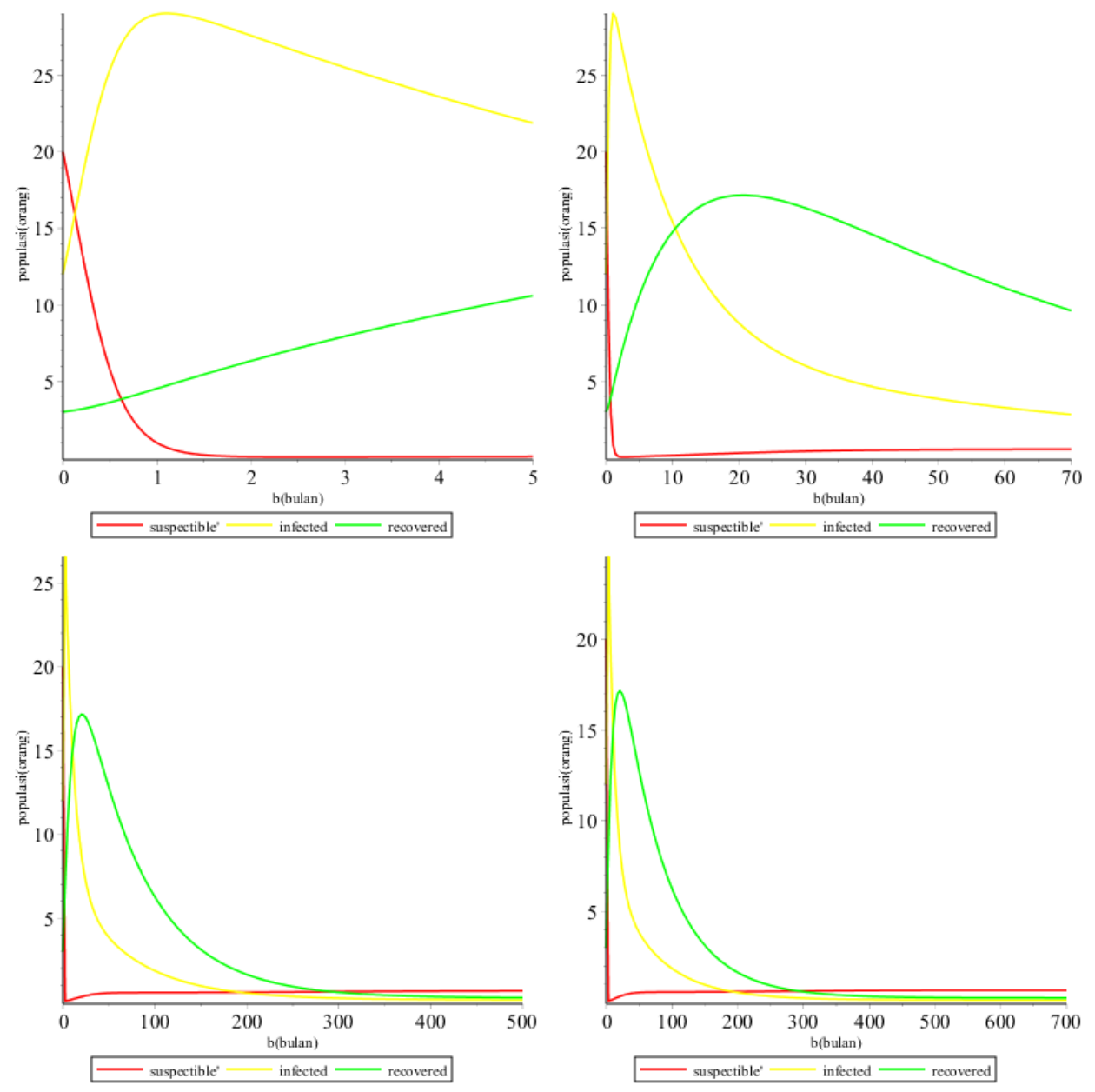

Gambar 3. Dinamika populasi pada kondisi $R_{0}>1$

Pada Gambar 2 dapat dilihat bahwa semua populasi akan menuju titik tetap endemik pecandu game online $\left(E_{2}\right)=(s=0.66, i=0.11, r=0.23)$. Populasi suspectible (merah) akan menurun kemudian naik sebelum bulan ke-10 dan akan stabil disekitar bulan ke40. Populasi infected (kuning) akan meningkat kemudian pada saat bulan ke 1 populasi infected (kuning) akan menurun dan akan stabil pada saat bulan ke-400. Populasi recovered (hijau) akan naik kemudian turun di sekitar bulen ke-20 dan menjadi stabil pada bulan ke-600.

\section{Kesimpulan}

Dari data diatas dapat disimpulkan bahwa dinamika populasi pecandu game online terdapat dua kondisi yaitu $R_{0}<1$ dan $R_{0}>1$.

a. Jika $\alpha<\beta+\mu+\theta$ maka dinamika populasi pecandu game online berada pada kondisi $R_{0}<1$ sehingga grafik menuju di sekitar titik tetap bebas pecandu game online $\left(E_{1}\right)=(s=1, i=0, r=0)$ dan pada saat tertentu populasi pecandu game online akan menghilang.

b. Jika $\alpha>\beta+\mu+\theta$ maka dinamika populasi pecandu game online berada pada kondisi $R_{0}>1$ sehingga populasi pecandu game online akan meningkat dan menjadi 
wabah tetapi pada saat tertentu akan menurun di sekitar titik tetap endemik yaitu

$\left(E_{2}\right)=(s=0.6591623470, i=0.1133956606, r=0.2274411530)$.

Jadi, untuk menghilangkan populasi pecandu game online maka kita harus mengurangi parameter $\alpha$ dan menaikkan parameter $\beta$.

\section{Referensi}

[1] C. Wijaya, “Apa Itu Kecanduan dan Bagaimana Cara Mengatasinya?,” 2017. [Online]. Available: https://www.daherba.com/apa-itu-kecanduan-danbagaimana-cara-mengatasinya.html.

[2] T. A. Putro and Nurjanah, "Perilaku Adiksi pada Pemain Game Online di Dinustech Semarang dan Dampaknya Terhadap Kesehatan," Visikes, vol. 12, no. 2, 2013.

[3] Soeitjiningsih, Tumbuh Kembang Remaja dan Aplikasi Internet Pendidikan. Jakarta: CV Sagung Seto, 2004.

[4] A. Usrotul, "Bermain Game dapat Menyebabkan Kematian," 2012. [Online]. Available: https:/www.kompasiana.com/usrotulafifah/bermain-game-dapatmenyebabkan-kematian.

[5] R. Baskoro, “Game Online Indonesia Tahun 2014: Ikhtisar dan Infografis," 2018. [Online]. Available: https://duniaku.idntimes.com/geek/culture/robibaskoro/game-online-indonesia-tahun-2014-ikhtirar-dan-infografis.

[6] A. P. J. I. Indonesia, "Hasil Survei Penetrasi dan Perilaku Pengguna Internet Indonesia 2017." [Online]. Available: https://apjii.or.id/content/read/39/342/Hasil-Survei-Penetrasi-dan-PerilakuPengguna-Internet-Indonesia-2017.

[7] O. Diekmann and J. Heesterbeek, Mathematical Epidemiology of Infectious Diseases. USA: John Wiley \& Sons, 2000.

[8] R. Resmawan and N. Nurwan, "Konstruksi Bilangan Reproduksi Dasar pada Model Epidemik SEIRS-SEI Penyebaran Malaria dengan Vaksinasi dan Pengobatan," J. Mat. Integr., vol. 13, no. 2, pp. 105-114, Dec. 2017.

[9] R. Resmawan and L. Yahya, "Sensitivity Analysis of Mathematical Model of Coronavirus Disease (COVID-19) Transmission," CAUCHY, vol. 6, no. 2, pp. 9199, May 2020.

[10] B. P. Statistik, “Sensus Penduduk 2010." [Online]. Available: https://sp2010.bps.go.id/index.php. 